\title{
APLIKASI BIBLIOKONSELING SEBAGAI SALAH SATU STRATEGI MEMBANTU KLIEN DALAM KONSELING
}

\author{
Oleh: Muh. Yusuf Hidayat*
}

\begin{abstract}
Counseling as technology of humanistic help needs appropriate strategy, so service subject gets advantage for itself. Bibliocounseling constitutes one of the help strategies by using information in the source library. This strategy can be made use of helping the client to improve health and so on. In order that, the counselor needs expansion bibliocounseling: goal, characteristic, client's problem, material, method, and evaluation. The result of bibliocouseling has been planned that can be presented with technique of self-management, minimal contact, management counselor, and counselor's direction. Its application, of course, it pays attention of principle such as truth and powerfulness information, efficient, advantage, client activity, and interest.
\end{abstract}

KEYWORDS: Bimbingan, konseling, bibliokonseling, biblioterapi

KONSELING dapat dipahami sebagai suatu strategi untuk membantu klien mengatasi masalahnya. Penggunaan strategi yang tepat guna dapat mempermudah tercapainya tujuan konseling. Dalam memilih strategi, konselor hendaknya mempertimbangkan berbagai faktor yang relevan, misalnya: ciri klien, jenis masalah, dan harapan klien dalam konseling. Faktor-faktor tesebut menjadi bahan pertimbangan untuk menjawab pertanyaan mengapa dipilih pendekatan atau strategi konseling tertentu dan bukan yang lain.

Salah satu strategi yang menjadi alternatif pilihan konseling adalah bibliokonseling atau biblioterapi konseling yang menggunakan bahan pustaka. Bibliokonseling yang sudah dirancang oleh konselor dengan mempertimbangkan tujuan, ciri klien, material, sasaran, metode, dan evaluasi akan membantu klien memperoleh informasi tentang masalahmasalah yang dihadapinya. Perolehan informasi tersebut dapat mengubah tingkah laku kalau klien betul-betul berusaha mematuhinya. Setelah

*Magister Pendidikan dalam bidang Bimbingan dan Konseling dari Universitas Negeri Malang ini adalah dosen tetap Fakultas Tarbiyah dan Keguruan UIN Alauddin Makassar. Saat ini ia sedang menjabat sebagai Ketua Program Studi Pendidikan Fisika pada Fakultas Tarbiyah dan Keguruan UIN Alauddin Makassar. 
membaca sebuah buku misalnya, klien dapat mengubah tingkah lakunya dengan jalan mengikuti anjuran-anjuran, nasehat, pandangan-pandangan hidup, kebajikan-kebajikan hidup yang ditulis oleh pengarang dalam dalam buku tersebut atau mengubah sikapnya terhadap suatu hal yang selama ini dianutnya. Ia dapat meniru tingkah laku tokoh ideal dalam suatu bacaan dan menghindari tingkah laku yang dianggapnya tidak baik dari tokoh yang tidak disenangi. ${ }^{1}$

Perancangan bibliokonseling yang komprehensif tentu melibatkan perancang, prosedur, dan komponen-komponen perancangan, sebagaimana perancangan suatu bentuk pengajaran. Meskipun demikian, konselor dapat melaksanakan bibliokonseling secara sederhana dengan jalan memanfaatkan informasi-informasi apa adanya yang terdapat dalam bahan bacaan: buku, artikel, bab atau subbab, novel, cerita, tanpa mengabaikan relevansi material dengan masalah klien, teknik bibliokonseling, dan tujuan khusus konseling.

\section{MASALAH-MASALAH YANG DITANGANI DENGAN BIBLIOKON- SELING}

Elizabeth Hurlock mengemukakan bahwa penyebab masalah yang dihadapi oleh klien terbagi atas dua penyebab, yaitu: pertama, penyebab yang mempengaruhi; dan kedua, penyebab yang menggerakkan. Lebih jauh dikatakan bahwa suatu masalah muncul tergantung pada ada tidaknya penyebab pertama. Kekuatan penyebab pertama menjadikan penyebab kedua mendorong klien untuk menuju pada kenakalan. ${ }^{2}$

Terkait dengan penyebab yang mempengaruhi, para pakar telah melakukan identifikasi sebagai berikut:

- Tingkat kecerdasan yang rendah, kurang mampu merencanakan dan berpikir panjang.

- Kurang sempurna bentuk fisik maupun seksual, yang menimbulkan perasaan kurang yakin, hingga mencari kompensasi dengan tingkah laku anti sosial.

- Pandangan negatif terhadap pendidikan, diawali oleh kegagalan akademik, putus sekolah atau kekecewaan lainnya.

- Kebingungan terhadap nilai-nilai moral.

- Ditolak oleh kelompok yang mempunyai status, tetapi justru diterima oleh gang-gang nakal.

- Peran mass media yang menampilkan kegemerlapan dan kehebatan.

- Kondisi rumah tangga yang tidak harmonis, kurang respek dari orangtua, kurang kasih sayang, tidak ada keakraban antara anggota keluarga, 
dan disiplin kasar, dapat membuat klien cenderung melakukan tindakan yang menyakitkan hati orangtuanya.

- Memiliki konsep diri yang tidak menguntungkan, rendah diri dan tidak yakin, maka dalam berbagai situasi di mana ada kesempatan untuk mengembangkan ego, mereka akan membual atau melakukan tindakan untuk menarik perhatian.

Selanjutnya, para pakar juga telah melakukan identifikasi terhadap penyebab yang menggerakkan, sebagai berikut:

- Keinginan untuk memperoleh benda-benda yang lebih baik dan tidak puas dengan apa yang dimiliki, diperkuat dengan adanya iklan.

- Emosi yang kuat, tetapi tidak belajar bagaimana mengendalikannya dan mengontrolnya.

- Kebosanan, ditambah kurang tanggung jawab dan terlalu sedikit memperoleh kesempatan dalam berprestasi dan berkreasi, membuat klien mencari kelegaan dengan cara yang negatif.

- Perasaan rendah diri terhadap teman sebaya, baik secara fisik maupun mental atau sosial; gerakan untuk melanggar hukum untuk membuktikan bahwa ia tidaklah inferior.

- Keinginan mandiri yang dicari lewat perbuatan melanggar hukum.

- Keinginan untuk diterima, terutama oleh kelompok yang dianggapnya cocok, sehingga klien mengikuti apa kehendak kelompok.

- Keinginan untuk dicintai dan kepuasan seksual. ${ }^{3}$

Konselor perlu mengidentifikasi kedua faktor tersebut di atas dalam menentukan jenis masalah yang dialami klien. Berdasarkan identifikasi penyebab masalah, konselor dapat memilih secara cermat strategi layanan bantuan dalam upaya mengatasi masalah klien. Ketika memilih suatu strategi bantuan, tuntutan profesional pertama yang harus dipenuhi konselor adalah alasan-alasan rasional sebagai landasan keputusan. Dalam menjalankan tugas-tugas pelayanan dan pengelolaan konseling tenaga profesi konseling pada umumnya bekerja sendiri, sedangkan untuk programprogram tertentu bekerja sama dengan tenaga profesional lainnya.

Adapun hal tentang cara atau prosedur teknis pelaksanaan merupakan tuntunan profesional yang seharusnya sudah dikuasai dalam pelatihan awal konselor. Jika tidak, teknik itu akan dipelajari dalam jabatan karena penguasaan suatu teknik baru merupakan tuntutan profesional pula.

Untuk menjalankan tugas profesionalisasi konseling, konselor harus menguasai bidang-bidang pelayanan, yaitu:

- Bidang pelayanan kehidupan pribadi, meliputi membantu klien menilai kecakapan, minat, bakat, dan karakteristik keperibadian diri sendiri untuk mengembangkan diri secara realistik. 
- Bidang pelayanan kehidupan sosial, meliputi klien menilai dan mencari alternatif hubungan sosial yang sehat dan efektif dengan teman sebaya atau dengan lingkungan sosial yang lebih luas.

- Bidang pelayanan kegiatan belajar, meliputi membantu klien dalam kegiatan belajar dalam rangka mengikuti jenjang dan jalur pendidikan tertentu dan/atau dalam rangka menguasai sesuatu kecakapan dan keterampilan tertentu.

- Bidang pelayanan kehidupan berkeluarga, yaitu membantu klien dalam mencari dan menetapkan keputusan berkenaan dengan rencana perkawinan dan/atau kehidupan berkeluarga yang dijalaninya.

- Bidang pelayanan kehidupan keberagamaan, meliputi membantu kien dalam memantapkan diri berkenaan dengan perilaku keberagamaan menurut agama yang dianutnya. 4

Sehubungan dengan bidang pelayanan profesional dalam pemilihan suatu metode, konselor hendaknya mengidentifikasi masalah-masalah dan jenis klien yang cocok di atas dengan strategi bibliokonseling. Masalah itu terdapat dalam berbagai jenis dan tingkat asal memiliki ciri tertentu. Ciri itu ialah:

- Klien kurang dalam hal: informasi, wawasan, pemahaman, strategi dan metode pemecahan masalah.

- Dalam masalah tertentu klien lebih percaya pada buku atau pengarang tertentu untuk mengubah tingkah lakunya ketimbang konselor.

- Klien butuh latihan praktis yang ditulis dalam sebuah buku.

- Klien yang ingin menghemat waktu.

- Klien yang mampu mengubah tingkah lakunya (self-manage).

- Klien yang malu atau gugup mengemukakan masalahnya pada konselor. ${ }^{5}$

Jenis atau tingkat masalah yang kiranya cocok ditangani dengan strategi bibliokonseling: masalah keseharian, pendidikan, pekerjaan, kesehatan, modifikasi sikap sosial dan kepribadian. Wujud masalah itu seperti tidak tahu cara belajar efektif, sulit menghilangkan rasa malu, tidak mampu bersikap asertif, kurang percaya diri, sulit menurunkan berat badan, menghilangkan kebiasan merokok atau ketergantungan pada alkohol.

\section{MERANCANG MATERIAL BIBLIOKONSELING}

Merancang material bibliokonseling tidak ubahnya dengan merancang pembelajaran. Oleh sebab itu, komponen-komponen pembelajaran seperti tujuan, material, ciri klien, dan pendekatan dan teknik perlu diperhatikan. Berikut dikemukakan beberapa komponen yang dianggap sangat penting dalam merancang bibliokonseling. 


\section{Tujuan Bibliokonseling}

Secara umum, tujuan bibliokonseling sama dengan tujuan bimbingan konseling yakni membantu klien agar mencapai kesejahteraan hidup. Secara khusus, tentu saja, bibliokonseling bertujuan memecahkan masalah yang dihadapi klien. Sehingga tujuan khusus bibliokonseling sangat bergantung pada jenis masalah klien serta harapan klien dalam meghadapi masalah.

Sebagai contoh, sekolompok klien mengalami masalah ketergantungan pada ekstasi atau pil koplo atau putaw. Dalam kasus ini, tujuan bibliokonseling dapat dirumuskan seperti tujuan pembelajaran walaupun kata kerja yang digunakan tidak terlalu operasional. Tujuan itu sebagai berikut: setelah mengikuti bibliokonseling klien dapat:

- Menyebutkan jenis-jenis ekstasi.

- Menyebutkan akibat-akibat yang diderita oleh pemakai ekstasi.

- Membedakan pengaruh masing-masing jenis ekstasi terhadap penderitanya.

- Memahami sebab-sebab sosial-psikologis yang mendorong klien menenggak ekstasi.

- Memahami cara-cara berhenti dari ekstasi.

- Mengadakan kontrak baik kepada diri sendiri atau kepada kelompok dan konselor bahwa klien mau berhenti total dari ekstasi.

- Mengikuti latihan pribadi atau kelompok seperti relaksasi, yoga, kontemplasi sebagai salah satu wujud kontraknya.

- Menyadari akibat yang ditimbulkan oleh ekstasi.

- Mempertimbangkan perlu tidaknya menggunakan ekstasi.

- Mengambil keputusan untuk berhenti dari ekstasi. ${ }^{6}$

Tujuan-tujuan tersebut dapat dijabarkan lebih khusus dan kongkret dalam setiap kali pertemuan.

\section{Pengembangan Material Bibliokonseling}

Bertolak dari pengertian bahwa bibliokonseling ialah konseling dengan menggunakan bahan pustaka, maka sumber material bibliokonseling diambil dari bahan bacaan baik yang terdapat dalam buku, novel, cerita, artikel dalam koran dan sebagainya. Material yang digunakan biasanya tentang cara-cara menyelesaikan suatu masalah. Hendaknya buku ini tidak terlalu tebal, serta mempunyai bahasa dan ilustrasi yang menarik. Demikian pun tulisan-tulisan surat kabar berupa artikel, rubrik konsultasi, surat pembaca, dipilih yang relevan dengan masalah yang dialami oleh klien. 
Contoh material bibliokonseling, jika klien mengalami beberapa masalah emosional yang menyebabkan ia menutup dirinya dalam pergaulan, maka konselor menggunakan buku: Mengapa Takut Bersifat Terbuka?, tulisan John Powel, yang diterjemahkan oleh Yayasan Cipta Loa Caraka, Jakarta tahun 1995. Jika klien itu mengalami masalah ekstasi, maka konselor menyuruh membaca buku berjudul: Ecstasy and Putauw, karangan Herlianto, terbitan Kalam Hidup, Bandung, 1996.

Material bibliokonseling yang telah dikumpulkan dari berbagai sumber bacaan itu dikembangkan dalam bentuk konseling, baik kelompok maupun individual. Langkah-langkah bibliokonseling mengikuti langkah suatu pendekatan konseling, misalnya Rational Emotive Therapy. Oleh karena itu, konselor perlu merumuskan tujuan bibliokonseling secara umum, mengidentfikasi ciri klien yang butuh layanan bibliokonseling secara umum, menuliskan kompetensi dasar pelaksanaan bibliokonseling, menentukan material seperti seleksi dan mencocokkan dengan masalah dan tujuan klien, mengembangkan strategi bibliokonseling dengan menggunakan manual bantu diri atau arahan terapis reinforecement atau tanpa reinforcement, dan mengadakan evaluasi terhadap hasil bibliokonseling secara keseluruhan atau komponen-komponen pengembangannya.

\section{Landasan Kode Etik Layanan Bantuan Bibliokonseling}

Untuk menjalin komunikasi antara konselor dengan klien, maka seorang konselor harus memperhatikan kode etik pelaksanaan konseling, terutama dalam memelihara hubungan dengan klien. Adapun hal tersebut, yaitu:

- Konselor harus menghormati harkat pribadi, integritas, dan keyakinan klien.

- Konselor harus menempatkan kepentingan kliennya di atas kepentingan pribadinya. Demikian pula dia tidak boleh memberikan layanan bantuan di luar bidang pendidikan, pengalaman, dan kemampuan yang dimilikinya.

- Dalam menjalankan tugasnya, konselor tidak mengadakan pembedaan klien atas dasar suku, bangsa, warna kulit, agama atau status sosial ekonomi.

- Konselor tidak akan memaksa untuk memberikan bantuan kepada seseorang dan tidak akan mencampuri urusan pribadi orang lain tanpa seizin dari orang bersangkutan.

- Konselor bebas memilih siapa yang akan diberi bantuan, tetapi dia harus memperhatikan setiap permintaan bantuan, lebih-lebih dalam keadaan darurat atau apabila banyak orang yang menghendaki. 
- Kalau konselor sudah turun tangan membantu seseorang, maka dia tidak akan melalaikan klien tersebut, walinya atau orang yang bertanggung jawab padanya.

- Konselor harus menjelaskan kepada klien sifat hubungan yang sedang dibina dan batas-batas tanggung jawab masing-masing, khususnya sejauhmana dia memikul tanggung jawab terhadap klien.

- Hubungan konselor mengandung kesetiaan ganda kepada klien, masyarakat, atasan, dan rekan-rekan sejawat.

- Konselor tidak akan memberikan bantuan profesional kepada sanak keluarga, teman-teman karibnya, apabila hubungan profesional dengan oarng-orang tersebut mungkin dapat terancam oleh kaburnya peranan masing-masing. ${ }^{7}$

Dari kode etik di atas, perlu disadari oleh para konselor untuk melaksanakan konseling kepada klien yang memerlukan layanan secara profesional.

\section{Teknik Bibliokonseling}

Dalam pelaksanaan bibliokonseling, konselor harus memahami dan mempraktekkan teknik-teknik dasar konseling. Teknik dasar ini digunakan dalam wawancara konseling. Teknik tersebut meliputi:

- Teknik menerima klien.

- Mengatur sikap dan jarak duduk.

- Melakukan kontak mata.

- Teknik mendengar, memahami, dan merespon.

- Membangun kontak psikologis.

- Mengadakan penstrukturan.

- Mengajak klien berbicara.

- Memberikan dorongan minimal.

- Mengajukan pertanyaan terbuka.

- Memberikan refleksi.

- Menyimpulkan.

- Menafsirkan.

- Mengkonfrontasikan.

- Meruntuti pembicaraan.

- Mengelola suasana diam.

- Mengelola transferensi dan kontratransferensi.

- Menafsirkan pengalaman masa lalu.

- Mengelola asosiasi bebas.

- Menilai hasil konseling.

- Menyusun laporan konseling. ${ }^{8}$ 
Data yang terkumpul dalam wawancara konseling menjadi dasar pengambilan keputusan penggunaan strategi bibliolonseling. Brown mengemukakan empat teknik yang dapat digunakan dalam menggunakan model bibliokonseling, yaitu: 1) kelola sendiri, 2) kontak minimal, 3) kelola konselor, dan 4) arahan konselor. ${ }^{9}$

Untuk mendapatkan pemahaman yang memadai tentang keempat model bibliokonseling di atas, maka berikut ini dipaparkan uraian teknikteknik tersebut, yaitu:

\section{Teknik Kelola Sendiri}

Dalam teknik ini, konselor hanya mengaturkan judul buku, bab atau subbab, dan artikel yang hendaknya dibaca klien. Selanjutnya, klien sendiri yang aktif membaca, memahami, dan mengubah tingkah lakunya. Oleh karena itu, tehnik ini tidak memerlukan kehadiran seorang konselor kecuali pemantauan untuk mengetahui sejauhmana buku tersebut dibaca dan apakah ada perubahan tingkah laku klien. Material bibliokonseling yang digunakan dalam tehnik ini biasanya bersifat panduan atau petunjuk sehingga klien dapat memahami dan mengerjakannya dengan mudah.

\section{Teknik Kontak Minimal}

Teknik ini mengacu pada kondisi kontak minimal berupa pertemuan sekali-sekali, surat menyurat, telepon dengan petugas yang profesional atau para profesional yang terlatih. Sekali dalam sebulan, konselor dengan klien mengadakan pertemuan di ruang konseling ataupun di ruang tertentu seperti perpustakaan, klien menelpon konselor atau mengadakan korespondensi. Material bibliokonseling pada dasarnya sama dengan teknik kelola sendiri. Material itu merupakan bunga rampai dari bentukbentuk pertemuan dan pemantauan diri, deskripsi kegiatan dan latihanlatihan, ringkasan singkat tentang prosedur khusus dari suatu bentuk bibliokonseling.

\section{Teknik Kelola Konselor}

Teknik ini mengacu pada kondisi-kondisi yang dikelola oleh konselor seperti mengadakan pertemuan secara teratur dengan pemimpin kelompok atau sumber lain yang tetap berpedoman pada material bibliokonseling. Material tersebut dirancang untuk melatih konselor-konselor agar mereka dapat membantu kliennya dalam mengimplementasikan prosedur atau program khusus. Walaupun demikian, banyaknya frekuensi kontak langsung bukan merupakan syarat utama. Materialnya pun tidak terlalu sulit sehingga tidak sepenuhnya bergantung pada konselor. Tujuan penge- 
lolaannya adalah membahas material bibliokonseling dan mendapatkan bantuan dalam menerapkan prosedur-prosedur atau saran dari bahan bacaan tersebut. Misalnya, dalam suatu pertemuan, konselor mengatakan kepada beberapa anak SMP yang menglami kesulitan berkomunikasi melalui telepon: bacalah petunjuk cara menggunakan dengan sopan. Setelah beberapa menit, konselor menyuruh seorang klien membaca petunjuk pertama yakni menyebut nama dan alamat. Dalam hal ini, konselor memperagakan atau menyuruh klien menyebut nama dan alamat, serta mengikuti petunjuk-petunjuk selanjutnya.

\section{Teknik Arahan Konselor}

Teknik ini mengacu pada model tradisional dan wawancara mingguan sehingga kontak merupakan dasar satu-satunya untuk melaksanakan konseling kelompok. Dikatakan kontak merupakan dasar pelaksanaan karena diasumsikan bahwa orang awam tidak akan memahami atau tidak mampu mengimplementasikan program untuk dirinya sendiri. Asumsi tersebut membawa konsekuensi profesional bagi konselor, yakni ia perlu mempunyai latar belakang dan keterampilan untuk belajar menerapkan program dari manual tersebut. Buku-buku semacam ini biasanya berisikan material dan latihan yang hanya mampu dilaksanakan oleh konselor atau sumber lain yang telah terlatih. Misalnya, "mari berkontemplasi untuk kesehatan jiwa" memerlukan konselor yang bisa beryoga atau berkontemplasi. Jadi, jenis bidang bantuan adalah kontak yang intensif dan teratur.

\section{Prinsip-prinsip Penggunaan Bibliokonseling}

Sebagaimana teknik-teknik konseling kelompok, bibliokonseling mempunyai prinsip-prinsip tertentu yang hendaknya ditaati sebelum dan selama pelaksanaan. Prinsip-prinsip itu menurut Engles terdiri dari tujuh prinsip, yaitu :

- Buku-buku atau artikel yang disarankan konselor harus mengandung kebenaran dan memiliki daya pengubah.

- Konselor memiliki pengetahuan terhadap buku-buku yang disarankannya.

- Yang dimaksud dengan waktu di sini adalah ketepatan menggunakan bibliokonseling dan keefektifannya.

- Hasil bacaan klien perlu didiskusikan kecuali teknik kelola sendiri.

- Daftar buku-buku yang disarankan.

- Dosis bacaan yang lebih kecil, lebih membantu daripada dosis yang banyak dan luas. 
- Kemenarikan. Buku yang mungil, ada ilustrasi tingkah laku tertentu, metode yang bervariasi dapat membuat pelaksanaan bibliokonseling menjadi menarik. ${ }^{10}$

Ketujuh prinsip bibliokonseling di atas dapat diberi uraian secara naratif, sebagai berikut:

Prinsip pertama adalah buku-buku atau artikel yang disarankan konselor harus mengandung kebenaran dan memiliki daya pengubah. Dalam hal ini konselor hendaknya kritis mempertanyakan kebenaran isi buku itu. Beberapa faktor pertimbangan yang perlu digunakan seperti komentar orang lain terhadap sebuah buku, jika pernah diresensi, apa kelebihannya, bila perlu dipertanyakan bukti empiriknya. Jika material bibliokonseling berupa artikel, faktor pertimbangannya adalah keahlian atau keprofesionalan penulis atau pengasuh sebuah rubrik, popularitas sebuah surat kabar atau majalah.

Prinsip kedua adalah konselor memiliki pengetahuan terhadap bukubuku yang disarankannya. Prinsip ini mempersyaratkan konselor terlebih dahulu mempelajari buku-buku atau tulisan dari sumber lain sebelum menyarankan klien membacanya, Konselor yang melimpahkan klien kepada buku-buku yang tidak dikenal sebelumnya dapat mengakibatkan klien tersesat dan gagal memenuhi kebutuhannya. Kegagalan memahami buku-buku yang disarankan dapat membawa efek ketidaksenangan klien terhadap buku-buku tersebut, Oleh karena itu, konselor hendaknya mengingat baik judul-judul itu. Bila perlu konselor sudah menyiapkan daftar isi buku, untuk umur berapa, pengalaman apa yang akan diperoleh, dan tingkat kesulitan bahasa yang digunakan.

Prinsip ketiga adalah waktu, yaitu ketepatan menggunakan bibliokonseling dan keefektifannya. Waktu yang tepat adalah ketika klien mempunyai resistensi yang rendah, klien sedang berjuang melawan perasaan tertentu, klien gagal berkali-kali dalam memahami sesuatu hal, klien butuh informasi sehubungan dengan masalahnya. Demikian waktu yang digunakan untuk membaca sebuah buku atau menjalani suatu latihan atau petunjuk hendaknya tidak terlalu panjang. Jika banyak waktu yang dibutuhkan, maka konselor perlu merancangnya dalam beberapa pertemuan singkat.

Prinsip keempat adalah diskusi. Hasil bacaan klien perlu didiskusikan kecuali teknik kelola sendiri. Barangkali juga klien membutuhkan klarifikasi atau penguatan terhadap suatu gagasan dalam buku tersebut yang baginya terkesan dan sangat berharga. Sering gagasan yang terdapat dalam halaman bacaan tertentu dapat dibaca dengan keras agar klien merasa jelas dan dikuatkan dalam diskusi. Hal ini penting agar distorsi 
atau salah pengertian dapat diperbaiki pada waktu itu dan ketika itu terjadi evaluasi kritis. Bahkan klien dapat menyangsikan buku tersebut dengan menanyakan otoritas pengarang buku dan kebaruan informasi dalam buku tersebut.

Prinsip kelima adalah daftar buku-buku yang disarankan. Daftar buku dan tabel daftar isi perlu dicetak agar dapat merangsang klien untuk membaca buku-buku tersebut. Buku-buku dan pamflet yang kiranya berguna untuk dibaca hendaknya diletakkan pada ruang tunggu konseling sehingga klien dapat meminjamnya.

Prinsip keenam adalah dosis becaan yang lebih kecil. Dosis bacaan yang lebih kecil, lebih membantu daripada dosis yang banyak dan luas. Sebuah buku kecil, artikel atau pamflet sering lebih berguna daripada sebuah buku tebal. Di samping itu, hal ini lebih mudah bagi konselor menunjuk poin penting dalam bacaan itu karena material yang terlalu banyak dapat membosankan klien dan cendrung dibaca sedikit saja.

Prinsip ketujuh adalah kemenarikan. Buku yang mungil, ada ilustrasi tingkah laku tertentu, dan metode yang bervariasi dapat membuat pelaksanaan bibliokonseling menjadi menarik. Buku itu bisa berupa bukubuku saku yang dapat dibawa ke mana-mana, bahasannya menarik dan sedikit sugestibel. Metodenya dapat dibuat bervariasi dan atau gabungan antara membaca dan diskusi, diskusi dan praktek, membaca dan melatih diri, reinforcement berjadwal dan tidak berjadwal, dan sebagainya.

\section{PENUTUP}

Bibliokonseling merupakan salah satu strategi bantuan. Sebagai strategi, klien menawarkan tujuan, material, dan metode tersendiri. Diharapkan konselor dapat memanfaatkan informasi-informasi yang sudah ada dalam buku, majalah, surat kabar sebagai material bibliokonseling. Lebih daripada itu, konselor sekolah dapat merancang sendiri bibliokonseling sesuai dengan jenis layanan yang ditetapkannya.

Bibliokonseling yang sudah dirancang hendaknya diujicobakan pada kelompok-kelompok tertentu. Paling tidak, rancanagan bibliokonseling itu dicoba di dalam kelas dengan menggunakan riset aksi dalam kelas. Jika material dan metode pelaksanaannya tidak efektif, maka perbaikan dapat dilaksanakan sambil bibliokonseling berlangsung. Akhirnya, konselor dapat menemukan material yang tepat guna. Dengan demikian bibliokonseling diharapkan menjadi salah satu alternatif strategi bantuan kepada klien. 


\section{CATATAN AKHIR:}

1. B. J. Zucaro, "The Use of Bibliotherapy Among Sixth Graders to Affect Attitude Change Toward American Negroes", Dissertation Abstracts International, 1972, h. 13-40.

2. E. B. Hurlock, Developmental Psychology, New York: McGraw-Hill Book Company, 1974, h. 124.

3. E. B. Hurlock, Developmental Psychology, h. 125-126.

4. DIKNAS, Dasar-dasar Standardisasi Profesi Konseling, Jakarta: P2TA DIKTI, 2004, h. 19.

5. Rijordan, R. J. Wilson, dan S. Linda, Bibliotherapy: Does It Work? Journal of Counseling and Development, 1989, edisi 67, h. 506-507.

6. J. J. Muro dan D. C. Dinkmeyer, Counseling in the Elementary and Middle Schools: A Pragmatic Approch, Iowa, 1975, h. 100.

7. DIKNAS, Dasar-dasar Standardisasi Profesi Konseling, h. 80.

8. DIKNAS, Dasar-dasar Standardisasi Profesi Konseling, h. 53.

9. S. D. Brown dan R. W. Lent (eds), Handbook of Counseling Psychology, New York: A Wiley-Interscience Publication, John Wiley \& Sons,1984, h. 25.

10. F. A. Schrank dan D. W. Engels, "Bibliotherapy as Counseling Adjunct: Research Findings", The Personnel and Guidance Journal, 1999, h. 143.

\section{DAFTAR PUSTAKA:}

Zucaro, B. J., "The Use of Bibliotherapy Among Sixth Graders to Affect Attitude Change Toward American Negroes", Dissertation Abstracts International, 1972.

Hurlock, E. B., Developmental Psychology, New York: McGraw-Hill Book Com-pany, 1974.

DIKNAS, Dasar-dasar Standardisasi Profesi Konseling, Jakarta: P2TA DIKTI, 2004.

Rijordan, R. J. Wilson, dan S. Linda, Bibliotherapy: Does It Work? Journal of Counseling and Development, 1989, edisi 67.

Muro, J. J. dan D. C. Dinkmeyer, Counseling in the Elementary and Middle Schools: A Pragmatic Approch, Iowa, 1975.

Brown, S. D. dan R. W. Lent (eds), Handbook of Counseling Psychology, New York: A Wiley-Interscience Publication, John Wiley \& Sons, 1984.

Schrank, F. A. dan D. W. Engels, "Bibliotherapy as Counseling Adjunct: Research Findings", The Personnel and Guidance Journal, 1999. 